\title{
Antecedents of E-Banking Services by Customers for the Selected Commercial Banks in Sylhet, Bangladesh
}

\author{
Mohammad Zahed Hossain ${ }^{1}$ \\ ${ }^{1}$ Senior Lecturer, Department of Business Administration, Leading University, Sylhet \\ Correspondence: Mohammad Zahed Hossain, Senior Lecturer, Department of Business Administration, Leading \\ University, Sylhet. E-mail: zahedbtc@ gmail.com
}

Received: October 29, 2016

Accepted: November 21, 2016

Online Published: December 14, 2016

doi:10.5539/ijef.v9n1p47

URL: http://dx.doi.org/10.5539/ijef.v9n1p47

\begin{abstract}
This study is conducted to identify customers view regarding cost effectiveness, time savings and security of different types of e-banking products like online banking, ATM banking, internet banking, mobile banking and telephone banking. E-banking is the alternative delivery channels that banks adopted for providing efficient banking services through the help of internet, computers, mobile phone etc. Banks' customers were considered as population and primary data were collected through questionnaire. Descriptive statistics and Chi-square test were used for analyzing the data. The results indicated that customers prefer ATM banking services most, next to follow mobile banking and online banking. The customers believed that all types of e-banking products save time and except telephone banking others types of e-banking products were secured. Online banking and ATM banking services were not considered as cost effective. Analysis indicated no relationship between online banking and different demographic variables. ATM banking services was highly influenced by most of the demographic variables whereas internet banking, mobile banking and telephone banking influenced by few demographic variables i.e. age groups, education level, and monthly income. The results help banks to develop varieties of e-banking products and formulate strategies by considering the demographic characteristics of the customers. Customers expect more users friendly e-banking products along with diversify features and suggested to develop latest e-banking products like mobile apps based banking for ensuring long term customers relationship, attracting potential customers and keeping existing customers that may ensure consistent growth and profit as well.
\end{abstract}

Keywords: E-banking, cost effective, alternative delivery channels, commercial banks

\section{Introduction}

E-banking or electronic banking is the alternative way of providing banking services through electronic means i.e. pc, tab, telephone etc. with the help of internet. E-banking service offered as online banking, internet banking, telephone banking, sms banking, Automated Teller Machine (ATM) service etc. Customers can withdraw and deposit money at any branches of the respective bank where they maintain their account and they also can be informed about current status of their account through online banking services. Internet banking empowering customers to do transaction like fund transfer; utilities bill payments, mobile recharge, online purchase payments etc by themselves. ATM card enable customers withdraw money anytime from ATM booth as well as make payments for purchase. Through Mobile banking customers are able to do transactions their own. Transactions can be done by instructing bankers through telephone by the customers. Today customers chose bank (s) base on different types of e-banking services offered by banks for making their financial transactions. Through e-banking products banks able to provide customize services that create long term customer relationship. Electronic banking has become important weapon for competing with rivalries that ensure sustainable growth and profitability.

Previous studies have identified that despite the attractiveness of electronic commerce for corporation, customers might be reluctant to utilize it (Riasi \& Pourmiri, 2015). Peoples react differently to adoption of technology some think that it may save time by making task easier while others concern about its perspective risk (Dillon \& Morris, 1996). Some developed countries introduced electronic banking through Automated Teller Machine (ATM) since 1980 then telephone banking was introduced in 1990. USA launched internet banking in 1995 (Sohail \& Shanmugham, 2003). Technology adoption helps organizations to reach their customers more easily 
(Lu et al., 2005; Winch \& Joyce, 2006). Through electronic banking services banks are able to provide quality services and gain competitive advantage (Jayawardhena \& Foley, 2000). E-Banking save customers' time and they can access more services any time that are not available in the bank branches (Baraghani, 2007). Sankari et al. (2015) proved that trust and perceived ease of use has positive and significant impact on adoption of internet banking. Devi and Malarvizhi (2010) concluded that ATM is more popular which is most cost effective. Spaho and Ramaj (2014) found that education and income level were significantly related to the use of electronic banking services. Rotchanakitumnual and Mark (2003) indicated that security of the internet is a major factor inhibiting wider adoption. Hanafizadeh et al. (2014) after analyzing 165 articles suggested some research opportunities like in Asia internet banking adoption is affected by some specific regional factors along with that they also encouraged for studying the comparative effects of a broader set of descriptive variables as they impact internet banking adoption.

Since electronic banking has different types of products like ATM banking, online banking, internet banking telephone banking and mobile banking but most of the previous works were conducted by considering only anyone of e-banking products. Very few comparative studies have been done to show association among demographic variables and different types of e-banking. Such types of work are not conducted in our country.

This study emphasized to derive relationship for each types of electronic banking with different demographic variables. This study focused on the relationship among different demographic variables i.e. gender, age groups, education levels, income levels \& occupations and various features of different types electronic banking products like online banking, ATM banking, internet banking, mobile banking and telephone banking.

The objectives of this paper are to identify customers view regarding cost effectiveness, time savings and security of different types of e-banking products; to find association with clients' demographic variables and cost effectiveness, time savings and security of different types of e-banking products like online banking, ATM banking, internet banking, mobile banking and telephone banking; to understand the views of customers to electronic banking compare to traditional banking and to understand customers responses to electronic banking based on awareness program.

\section{Literature Review}

E-commerce literature has studied the phenomenon of e-banking from different perspectives. Some researcher analyzed the adoption and growth of e-banking, whilst others describe the challenges and benefits to be gained from e-banking services as far as the organization is concerned.

Karimzadeh (2012) found that increased competition, changing business environments, globalization and the advancement of Information and Communications Technology are the important factors along with that have forced Banking and Financial services to change. Ridzwan1 et al. (2012) noticed that Innovativeness and Familiarity significantly influence users acceptance of e-Banking in this urban district in Malaysia. Vishnoi et al. (2014) observed that people are aware of e-banking as they feel it has advantages like convenience and saves time but they also feel that factors like security and privacy, trust, familiarity and speed seems hurdle in the acceptance of e-banking. Singh (2014) said that customer can do multiple things from the comforts of home or office with e-Banking - a one stop solution for all banking needs. They proposed top three critical success factors of e-banking, cost and promotion; security and privacy; ease of use. Dixit and Datta (2010) investigates many factors like security \& privacy, trust, innovativeness, familiarity, awareness level increase the acceptance of e-banking services among Indian customers. Their finding shows that in spite of users' security and privacy concern, adult customers are willing to adopt online banking if banks provide users necessary guidance. Khurshid (2014) showed that risk involved in e-banking is insignificant compared to its usefulness. Devi and Malarvizhi (2010) understand that the customers are satisfied with the quality of e-banking services. But they face technical as well as administrative and procedural problems. Karjaluoto et al. (2002) their finding depicts that bank managers can, by knowing the basic beliefs consumers hold about internet banking, create more effective customer communication, improve software and target prospects better concerning internet banking. There is wide agreement that internet banking will on the one hand have a great impact on the whole bank market, and on the other hand will be considered the most important retail banking delivery channel in the near future. Ismail and Osman (2012) identified eleven factors that affect the adoption of e-banking in Sudan. These factors include frequent breakdown of ATMs, inconvenient locations of ATMs and Electronic Points of Sale (EPOS), inaccessible internet, lack of means reporting technical problems, unclear legislations protecting e-transactions, slow banks response for correcting erroneous transactions, weak banks' role in raising clients awareness, unclear e-banking guidelines and instructions, frequent power cut offs, and high e-banking services' fees. Alam et al. (2010) present that banks perceive online banking as a powerful 'value-added' tool to attract 
and retain new customers while helping to eliminate costly paper handling and teller interactions. Online banking has managed to provide customers the convenience, efficiency, effectiveness, and most importantly, the speed needed in today's dynamic world.

\section{Research Methodology}

The study was mainly based on primary data. A questionnaire including both open-ended and close-ended questions was used for collecting raw data. Population of this study was the existing clients of the different commercial banks in Sylhet, Bangladesh. 200 useful samples were collected from existing customers of different commercial banks out of 300, representing $66.67 \%$ response rate. Data were collected in Sylhet, and conveniences sampling technique was used.

Factors included in this study were adopted from different published articles and determined by interview with bank executives. Data were analyzed through descriptive statistical tools and chi-square test. To measure the data five point Likert Scaling technique was used within the range of "strongly disagree" to "strongly agree". Higher mean value indicates positive consent of the respondents on respective issues. The p-value less or equal to 0.05 indicates the association between demographic variables and features of different types of e-banking products. SPSS was used for conducting the analysis.

\section{Results and Discussion}

The data analysis has been found out by the opinion of the respondents. While presenting, data charts and tables are used at relevant places. The demographic profile of the respondent is one of the factors that influence the adoption/non- adoption of technology based products and services. The demographic characteristics of the EBanking users of the sample respondents are given below:

Table 1. Profile of the respondents

\begin{tabular}{|c|c|c|c|c|c|}
\hline Gender & \multicolumn{2}{|c|}{ Male } & \multicolumn{3}{|c|}{ Female } \\
\hline Number & \multicolumn{2}{|c|}{146} & \multicolumn{3}{|c|}{54} \\
\hline Percentage of respondents & \multicolumn{2}{|c|}{73} & \multicolumn{3}{|c|}{27} \\
\hline Age(Years) & 20 and less & 21-30 & $31-40$ & $41-50$ & 50 and above \\
\hline Number & 5 & 84 & 64 & 34 & 13 \\
\hline Percentage of respondents & 2.50 & 42.00 & 32.00 & 17.00 & 6.50 \\
\hline Education & $\begin{array}{c}\mathrm{SSC} / \mathrm{HHC} \text { and } \\
\text { below }\end{array}$ & Undergraduate & Post Graduate & $\begin{array}{l}\text { M.phil And/or } \\
\text { Ph.D. }\end{array}$ & Others \\
\hline Number & 26 & 47 & 114 & 4 & 9 \\
\hline Percentage of respondents & 13 & 23.50 & $\mathbf{5 7 . 0 0}$ & 2.00 & 4.50 \\
\hline Occupation & Businessman & Professionals & Self employed & Service holder & Students \\
\hline Number & 45 & 11 & 13 & 121 & 10 \\
\hline Percentage of respondents & 22.50 & 5.50 & 6.50 & 60.50 & 5.00 \\
\hline Monthly Income (TK.) & 10,000 and less & $10,001-20,000$ & $20,001-50,000$ & $50,001-1,00,000$ & 100000 and above \\
\hline Number & 7 & 44 & 97 & 47 & 5 \\
\hline Percentage of respondents & 3.50 & 22.00 & 48.50 & 23.50 & 2.50 \\
\hline
\end{tabular}

* Self employed= dairy, poultry, building workers, mechanics.

From Table 1, it was observed that among the respondents, $73 \%$ are males and the rest $27 \%$ are females. About $45 \%$ of the respondents were below 30 years of age and 32\% were between 31 to 40 years of age. Majority $57 \%$ of the respondents have completed post graduates and 23\% have completed graduate degree. Almost $60 \%$ respondents were service holders, $22.50 \%$ were businessmen. Around $50 \%$ of the respondents had monthly income between tk.20,000 - tk.50,000 and near about 25\% had monthly income below tk.20,000.

Table 2. Preferences for E-banking services

\begin{tabular}{lcccccccc}
\hline E-Banking Services & R-1 & R-2 & R-3 & R-4 & R-5 & R-6 & R-7 & Total Scores \\
\hline ATM & 70 & 60 & 40 & 30 & 0 & 0 & 0 & 1170 \\
Mobile Banking & 40 & 30 & 30 & 50 & 30 & 20 & 0 & 940 \\
Online Banking & 27 & 29 & 38 & 20 & 36 & 49 & 1 & 840 \\
Internet Banking & 18 & 23 & 34 & 20 & 41 & 42 & 22 & 743 \\
Tele Banking & 0 & 21 & 12 & 22 & 43 & 55 & 47 & 560 \\
\hline
\end{tabular}


From Table 2, it was observed that respondents were requested to give their preferences among E-banking services between rank 1 to rank 7 and scoring in opposite direction like rank 1 equal to score 7 , rank 2 equal to score 6 and so on. Based on the score given by the respondents it was revealed that highest preferences given to ATM services score 1170, next preference was given to mobile banking with score 940 after that online banking is in third position with score 840 . Respondents were reluctant to telephone phone banking having minimum score 560. These findings are same as the findings of Devi and Malarvizhi (2010). The most frequent usage of ATM compared with others types of e-banking services is supported by (Spaho \& Ramaj, 2014; Mohamed \& Mohammed, 2012; Izogo et al., 2012; Wan et al., 2005).

Table 3. Cost effectiveness of different E-banking products

\begin{tabular}{|c|c|c|c|c|c|}
\hline & $\begin{array}{c}\text { Cost effectiveness of } \\
\text { Online banking }\end{array}$ & $\begin{array}{c}\text { Cost effectiveness of } \\
\text { ATM banking }\end{array}$ & $\begin{array}{c}\text { Cost effectiveness of } \\
\text { Internet banking }\end{array}$ & $\begin{array}{c}\text { Cost effectiveness of } \\
\text { Mobile banking }\end{array}$ & $\begin{array}{c}\text { Cost effectiveness of } \\
\text { Tele banking }\end{array}$ \\
\hline Mean & 3.0800 & 2.6150 & 3.8200 & 3.8350 & 3.5850 \\
\hline Std. Deviation & 1.26555 & 1.35126 & 0.93915 & 0.90658 & 1.10402 \\
\hline
\end{tabular}

From Table 3, it was observed that in respond to the cost effectiveness of different e-banking products respondents believed that they were paying more for ATM services compare to Online banking, Internet banking, Mobile banking, and Tele banking services. Among the different e-banking products respondents believed Mobile banking most cost effective, next to follow Internet banking, Tele banking, and Online bank. Findings differ from Devi and Malarvizhi (2010).

Table 4. Customers' response to the statement- "E-banking products save times"

\begin{tabular}{lcccc}
\hline & Online banking save time & ATM banking save time & $\begin{array}{c}\text { Internet banking save } \\
\text { time }\end{array}$ & $\begin{array}{c}\text { Mobile banking save } \\
\text { time }\end{array}$ \\
\hline Mean & 4.2700 & 4.5650 & 4.1500 & 4.1950 \\
Std. Deviation & 0.92812 & 0.76728 & 0.87827 & 3.6600 \\
\hline
\end{tabular}

From Table 4, it was observed that all most every respondent believed that all e-banking products save time. Among the various types of e-banking products respondents highly believed that ATM services enabled to save their times next online banking, mobile banking, internet banking and telephone banking. Since through all the e-banking products customers are able to do banking without physically visit to bank premises, waiting in line and paper work etc. so that e banking products are competent enough to save times.

Table 5. Customer response regarding security and privacy issues of E-banking products

\begin{tabular}{|c|c|c|c|c|c|}
\hline & $\begin{array}{c}\text { Online banking is } \\
\text { secure }\end{array}$ & $\begin{array}{l}\text { ATM banking is } \\
\text { secure }\end{array}$ & $\begin{array}{c}\text { Internet banking is } \\
\text { secure }\end{array}$ & $\begin{array}{c}\text { Mobile banking is } \\
\text { secure }\end{array}$ & $\begin{array}{c}\text { Tele banking is } \\
\text { secure }\end{array}$ \\
\hline Mean & 3.9750 & 4.1500 & 3.4650 & 3.1250 & 2.3600 \\
\hline Std. Deviation & 1.20066 & .86093 & 1.22322 & 1.39251 & 1.05640 \\
\hline
\end{tabular}

From the Table 5, it was noticed that except telephone banking others e-banking products online, ATM, internet and mobile banking services were secured. Respondents opined ATM services more secured next to follow online banking, internet banking and mobile banking.

Table 6. Chi Square results p-value for cost effectiveness of different types of e-banking services

\begin{tabular}{lccccc}
\hline & Age & Gender & Education & Occupation & Monthly Income \\
\hline Online Banking & & & & & $12.765(16)$ \\
Chi-square value $(d f)$ & $11.821(16)$ & $2.356(4)$ & $10.594(16)$ & 0.690 & $0.152(16)$ \\
p-value & 0.756 & 0.671 & 0.834 & & 0.261 \\
ATM Banking & & & & $19.054(16)$ & $29.093(16)$ \\
Chi-square value $(d f)$ & $28.011(16)$ & $12.606(4)$ & $29.003(16)$ & 0.266 & $\mathbf{0 . 0 2 3}$ \\
p-value & $\mathbf{0 . 0 3 2}$ & $\mathbf{0 . 0 1 3}$ & $\mathbf{0 . 0 2 4}$ & \\
\hline
\end{tabular}




\begin{tabular}{|c|c|c|c|c|c|}
\hline \multicolumn{6}{|l|}{ Internet Banking } \\
\hline Chi-square value $(d f)$ & $35.051(16)$ & $5.074(4)$ & $10.594(16)$ & $8.775(16)$ & $12.281(16)$ \\
\hline p-value & 0.004 & 0.280 & 0.834 & 0.922 & 0.724 \\
\hline \multicolumn{6}{|l|}{ Mobile Banking } \\
\hline Chi-square value $(d f)$ & $25.064(16)$ & $4.795(4)$ & $36.773(16)$ & $20.281(16)$ & $21.172(16)$ \\
\hline p-value & 0.069 & 0.309 & 0.002 & 0.208 & 0.172 \\
\hline \multicolumn{6}{|l|}{ Telephone Banking } \\
\hline Chi-square value $(d f)$ & $32.393(16)$ & $1.115(4)$ & $25.327(16)$ & $20.025(16)$ & $30.904(16)$ \\
\hline p-value & 0.009 & 0.892 & 0.064 & 0.219 & 0.014 \\
\hline
\end{tabular}

From Table 6, it was observed that the results of chi square test indicated significant association between the demographic variables and cost effectiveness of different e-banking products. From the analysis it is found that ATM banking has association with all democratic variables except occupation, internet banking showed association with different age groups, mobile banking has an strong association with education level and telephone banking indicated relation with age groups and relation with income level.

Table 7. Chi Square results p-value for time savings of different types of e-banking services

\begin{tabular}{|c|c|c|c|c|c|}
\hline & Age & Gender & Education & Occupation & Monthly Income \\
\hline \multicolumn{6}{|l|}{ Online Banking } \\
\hline Chi-square value $(d f)$ & $10.735(16)$ & $8.433(4)$ & $24.516(16)$ & $17.090(16)$ & $22.844(16)$ \\
\hline p-value & 0.826 & 0.077 & 0.079 & 0.380 & 0.118 \\
\hline \multicolumn{6}{|l|}{ ATM Banking } \\
\hline Chi-square value $(d f)$ & $19.844(12)$ & $0.706(3)$ & $14.427(12)$ & $21.439(12)$ & $16.921(12)$ \\
\hline $\mathrm{p}$-value & 0.070 & 0.872 & 0.274 & 0.044 & 0.153 \\
\hline \multicolumn{6}{|l|}{ Internet Banking } \\
\hline Chi-square value $(d f)$ & $26.283(16)$ & $4.042(4)$ & $33.532(16)$ & $12.407(16)$ & $23.676(16)$ \\
\hline p-value & 0.050 & 0.400 & 0.006 & 0.716 & 0.097 \\
\hline \multicolumn{6}{|l|}{ Mobile Banking } \\
\hline Chi-square value $(d f)$ & $32.382(12)$ & $4.465(3)$ & $23.996(12)$ & $9.931(12)$ & $16.518(12)$ \\
\hline p-value & 0.001 & 0.215 & 0.020 & 0.622 & 0.169 \\
\hline \multicolumn{6}{|l|}{ Telephone Banking } \\
\hline Chi-square value $(d f)$ & $19.112(16)$ & $13.905(4)$ & $22.378(16)$ & $11.646(16)$ & $39.775(16)$ \\
\hline p-value & 0.263 & 0.008 & 0.131 & 0.768 & 0.001 \\
\hline
\end{tabular}

From Table 7, it was observed that the results of chi square test indicated significant relation between the demographic variables and time savings benefit of different e-banking products. The result indicated relation between ATM banking and age, internet banking has association with age and education, mobile banking also showed relation with age and education, telephone banking has association with gender and income level.

Table 8. Chi Square results p-value for security of different types of e-banking services

\begin{tabular}{|c|c|c|c|c|c|}
\hline & Age & Gender & Education & Occupation & Monthly Income \\
\hline \multicolumn{6}{|l|}{ Online Banking } \\
\hline Chi-square value $(d f)$ & $14.430(16)$ & $4.909(4)$ & $18.062(16)$ & $20.836(16)$ & $20.939 \quad(16)$ \\
\hline p-value & 0.567 & 0.297 & 0.320 & 0.185 & 0.181 \\
\hline \multicolumn{6}{|l|}{ ATM Banking } \\
\hline Chi-square value $(d f)$ & $32.817(16)$ & $4.541(4)$ & $36.144(16)$ & $21.847(16)$ & $36.568(16)$ \\
\hline p-value & 0.008 & 0.338 & 0.003 & 0.148 & 0.002 \\
\hline \multicolumn{6}{|l|}{ Internet Banking } \\
\hline Chi-square value $(d f)$ & $40.447(16)$ & $2.034(4)$ & $48.271(16)$ & $22.316(16)$ & $23.970(16)$ \\
\hline p-value & 0.001 & 0.730 & 0.000 & 0.133 & 0.090 \\
\hline \multicolumn{6}{|l|}{ Mobile Banking } \\
\hline Chi-square value $(d f)$ & $29.961(16)$ & $6.659(4)$ & $15.530(16)$ & $17.436(16)$ & $21.234(16)$ \\
\hline p-value & 0.018 & 0.155 & 0.486 & 0.358 & 0.170 \\
\hline \multicolumn{6}{|l|}{ Telephone Banking } \\
\hline Chi-square value $(d f)$ & $15.666(16)$ & $10.078(4)$ & $14,551(16)$ & $19.048(16)$ & $34.842(16)$ \\
\hline p-value & 0.477 & $\mathbf{0 . 0 3 9}$ & 0.558 & 0.266 & 0.004 \\
\hline
\end{tabular}


From the analysis of the Table 8, it was notice that security issue of ATM banking services has association with different age groups, education level and income level. Internet banking security issue showed strong relation with age groups and education level. Mobile banking security has relation with age groups. Telephone banking security indicated association with gender and income level.

There were no association between demographic variables and online banking's cost effectiveness, time savings and security aspect. In Bangladesh all banks are providing online banking services because it is now become basic banking services along with that without online banking services bank can't provide others type of e-banking services.

\subsection{Customers' Response to the Statement- "E-Banking Services Are Relatively Better than Traditional Manual} Banking"

Table 9. Percentage of the respondents' opinion

\begin{tabular}{lcc}
\hline & Yes & No \\
\hline Number of respondents & 144 & 56 \\
Percentage of respondents & $\mathbf{7 2}$ & $\mathbf{2 8}$ \\
\hline
\end{tabular}

From Table 9, it was observed that through e-banking customers are empowered to do some transactions like fund transfer, installment payments of loan/deposit, utilities bills payment etc. and they also can make request for check book and stop check payments etc. without visiting bank premises physically. Since e-banking services are prompt, less burdensome and offer different types of benefits about $72 \%$ respondents believe that e-banking services are better than traditional banking services.

4.2 Customers' Response to the Question: Do You Think Banks Need to Take Various Types of Awareness Programs to Inform Customers about the Benefits of E-Banking Products?

Table 10. Respondents' opinions regarding awareness programs

\begin{tabular}{lcc}
\hline & Yes & No \\
\hline Number of respondents & 173 & 27 \\
Percentage of respondents & $\mathbf{8 6 . 5 0}$ & $\mathbf{1 3 . 5}$ \\
\hline
\end{tabular}

From Table 10, it was observed that maximum respondents, $86.50 \%$, opined that banks need to adopt promotional activities for disseminating information regarding the benefits of different types of e-banking products since they were not informed about the benefits.

\section{Conclusion}

E-Banking is the latest inclusion in banking transactions has opened up new window of opportunity to the banks and financial institutions. Data were analyzed through descriptive statistical analysis and chi-square test. All most every bank maintaining their own websites but all of them are not offering full fledges e-banking facilities in Bangladesh. Most of the e-banking users are young which indicates the bright prospects of e-banking services. Customers prefer ATM service most although they perceived that ATM service is not cost effective. All the respondents unanimously believe that e-banking products save time. Respondents also have positive views regarding security of e-banking products except telephone banking. About all customers opined that e-banking services are better than traditional banking services.

Analysis indicated no relation between online banking and different demographic variables. Cost effectiveness of different types of e-banking products have shown the following association; ATM banking with most of the demographic variables, internet banking and mobile banking has strong association with different age groups and education levels respectively; telephone banking has association with age groups and income level. In case of time savings of different e-banking products following relations have found ATM banking with occupation, both internet banking and mobile banking with age groups and education level and mobile banking with gender \& income level. Security of internet banking has strong association with age groups and education level; ATM banking has association with age, education \& income. Awareness program may increase e-banking users as they believe e-banking is better than traditional banking. Customers expect more users friendly e-banking products along with diversify features and they also suggested to develop latest e-banking products like mobile apps based banking for ensuring long term customers relationship, attracting potential customers and keeping existing 
customers that may ensure consistent growth and profit as well. The findings of this study help banks to develop different types of e-banking products that can be able to meet the needs of the customers.

The study findings are only suggestive since those findings rely solely on the use of questionnaires that might not capture the full nature and all the factors. Moreover, it might be difficult to generalize the findings of the present study given the shortness of the sample which was restricted to a very small number out of the total customers of different banks. Furthermore, there might be biased responses, and, therefore, might influence the findings and conclusions of the study.

Limitations all the demographic factors that influence e banking may not cover. Data were collected from concentrated area rather entire country. In some cases Respondents were given their opinions without enjoying the services.

Further research can be conducted to identify the factors that tempted potential users to adopt e-banking services such as: development of technology, changing lifestyle, essay access to internet, online payment facilities, social status, hazardous paper tasks in bank premises, queue in branches, risk of carrying cash, banks' promotional activities.

\section{References}

Alam, N., Magboul, I. H. M., \& Raman, M. (2010). Challenges Faced by Sudanese Banks in Implementing Online Banking: Bankers' Perception. Journal of Internet Banking and Commerce, 15(2), 1-9.

Baraghani, S. N. (2007). Factors Influencing the Adoption of Internet Banking (Unpublished Master's Thesis). Lulea university of Technology. Sweden. Retrieved from http://www.diva-portal.org/smash/get/diva2:1017415/FULLTEXT01.pdf

Devi, P. A., \& Malarvizhi, V. (2010). Customers' Perception of E-banking: Factor Analysis. IUP Journal of Management Research, 10(6), 7-19.

Dillon, A., \& Morris, M. (1996). User acceptance of new information technology: theories and models. In M. Williams (Ed.), Annual Review of Information Science and Technology (Vol. 31, pp. 3-32). Medford NJ: Information Today. Retrieved from http://www.ischool.utexas.edu/ adillon/BookChapters/User\%20acceptance.htm

Dixit, N., \& Datta, S. K. (2010). Acceptance of E-banking among Adult Customers: An Empirical Investigation in India. Journal of Internet Banking and Commerce, 15(2), 1-17.

Hanafizadeh, P., Keating, W. B., \& Khedmatgozar, R. H. (2013). A systematic review of Internet banking adoption. Telematics and Informatics, 31(3), 492-510. http://dx.doi.org/10.1016/j.tele.2013.04.003

Ismail, M. A., \& Osman, M. A. Y. (2012). Factors Influencing the Adoption of E-banking in Sudan: Perceptions of Retail Banking Clients. Journal of Internet Banking and Commerce, 17(3), 1-16.

Izogo, E. E., Nnaemeka, O. C., Onuoha, O. A., \& Ezema, K. S. (2012). Impact of Demographic Variables on Consumers' Adoption of E banking in Nigeria: An Empirical Investigation. European Journal of Business and Management, 4(17), 27-39.

Jayawardhena, C., \& Foley, P. (2000). Changes in the banking sector - The case of Internet banking in the UK. Journal of Internet research:Electronic Networking Application and Policy, 10(1), 19-30. https://doi.org/10.1108/10662240010312048

Karimzadeh, M. (2012). Electronic Banking Challenges in India: An Empirical Investigation. Interdisciplinary Journal of Contemporary Research in Business, 4(2), 31-45.

Karjaluoto, H., Mattila, M., \& Pento, T. (2002). Electronic banking in Finland: Consumer beliefs and reactions to a new delivery channel. Journal of Financial Services Marketing, 6(4), 346-361. https://doi.org/10.1057/palgrave.fsm.4770064

Khurshid, A., Rizwan, M., \& Tasneem, E. (2014). Factors contributing towards adoption of E-banking in Pakistan. International Journal of Accounting and Financial Reporting, 4(02), 437-455. http://dx.doi.org/10.5296/ ijafr.v4i2.6584

Lu, H., Hsu, C., \& Hsu, H. (2005). An empirical study of the effects of perceived risk upon intention to use online applications. Information Management \& Computer Security, 13(2), 106-120. http://dx.doi.org/10.1108/09685220510589299

Riasi, A., \& Pourmiri, S. (2015). Effects of online marketing on Iranian ecotourism industry: Economic, 
sociological, and cultural aspects. Management Science Letters, 5(10), 915-926.

Ridzwan1, I. U., Zain, N. A. M., Raizal, N. F., \& Khamsan, N. S. (2012). Factors Affecting Users'Acceptance of E-Banking in Damansara, Malaysia. International Proceedings of Economics Development and Research, 55(33), 163-166.

Rotchanakitumnual, S., \& Mark, S. (2003). Barriers to Internet banking adoption: A qualitative study among corporate customers in Thailand. The International Journal of Bank Marketing, 21(6/7), 312-323. http://dx.doi.org/10.1108/02652320310498465

Sankari, A., Ghazzawi, K., Danawi, S.,E., Nemar, S., E., \& Arnaout, B. (2015). Factors affecting the adoption of internet Banking in lebanon. International Journal of Management (ijm), 6(3), 75-86. Retrieved from http://citeseerx.ist.psu.edu/viewdoc/download?doi=10.1.1.695.3682\&rep=rep1\&type=pdf

Singh, M. (2014). Critical Success Factors in E-Banking: An Indian Perspective. International Research Journal of Management Science \& Technology, 5(9), 38-52.

Sohail, M. S., \& Shanmugham, B. (2003). E-banking and customer preferences in Malaysia: An empirical investigation. Information Sciences-Informatics and Computer Science. An international Journal, 150(3-4), 207-217. http://dx.doi.org/10.1016/S0020-0255(02)00378-X

Spaho, A., \& Tedis, R. (2014). Electronic Banking in Albania: A Statistical Analysis. International Journal of Research in Business Management, 2(12), 1-10.

Vishnoi, S., Varma, S., \& Thomas, G. (2014). A study of customers perception towards services of e banking (with special reference to gwalior city). Global Journal of Multidisciplinary Studies, 4(01), 95-101.

Wan, W. W. N., Luk, C. L., \& Chow, C. W. C. (2005). Customers' adoption of banking channels in Hong Kong. International Journal of Bank Marketing, 23(3), 255-272. http://dx.doi.org/10.1108/02652320510591711

Winch, G., \& Joyce, P. (2006). Exploring the dynamics of building, and losing, consumer trust in B2C eBusiness. International Journal of Retails and Distribution Management, 34(7), 541-555. http://dx.doi.org/10.1108/09590550610673617

\section{Copyrights}

Copyright for this article is retained by the author(s), with first publication rights granted to the journal.

This is an open-access article distributed under the terms and conditions of the Creative Commons Attribution license (http://creativecommons.org/licenses/by/4.0/). 